\title{
An Assessment of Biomass Supply Chain: A DEA Application
}

\author{
By Isotilia Costa Melo* \\ Athanasios Rentizelas ${ }^{*}$ \\ Paulo Nocera Alves Júniort \\ Jessica Suárez Campoli \\ Daisy Aparecida do Nascimento Rebelatto
}

\begin{abstract}
Renewable energy generation reduces carbon emissions and responds to the targets for renewable energy sources of most EU countries; it also enhances infrastructure resilience and creates flexibility of the energy matrix. However, the availability of biomass may drastically differ from country to country within the EU. In most cases, the most challenged countries to achieve high targets for sustainability are not those with a sufficiently large supply of biomass. Because of this, it is necessary to design new biomass supply chain networks and improve the existing networks. This paper aims to assess the efficiency of biomass alternative pathways of the supply network from South America to Europe. In this particular work, three scenarios of biomass using two transportation systems were investigated, i.e., transportation of wood logs, pellets and torrefied biomass in the country of origin by truck and train transportation. Efficiency was measured using a data envelopment analysis (DEA) model derived from CCR. The results present the most efficient supply chain alternatives and highlight the feasibility of establishing closer cooperation between Brazil and countries in Europe for green energy generation. This information can assist in the process of planning and decision-making to determine the practicability of the implementation of torrefaction facilities using the most efficient logistical pathways.
\end{abstract}

Keywords: Bio-based economy, Biomass, Brazil, Data Envelopment Analysis, Supply Chain Efficiency.

\section{Introduction}

In an uncertain economic environment, a development of strong energy supply chain networks is crucial. Most of the European countries have been pressed to reduce carbon emissions for generating power (European Comission, 2017). Among alternatives, there is electricity production through biomass consumption. In most of the cases, European countries, like the United Kingdom, do not have a sufficiently large stock of biomass for attending demand. On the

\footnotetext{
*Master Student, University of São Paulo, Brazil.

${ }^{\dagger}$ Lecturer, University of Strathclyde, UK.

${ }^{\ddagger} \mathrm{PhD}$ Student, University of São Paulo, Brazil.

-Master Student, University of São Paulo, Brazil.

Lecturer, University of São Paulo, Brazil.
} 
other hand, Brazil has the second largest forest in the world, corresponding to $54.4 \%$ of its territory (MMA, 2013).

In this context of international trade, DelfimNetto and Ikeda (2007) describe the process of economic development like a combination of thermodynamics and economics: it captures the available energy in the environment and dissipates it again in the productive process. For this reason, the first limiting factor of growth in a country is the availability of energy and the second is the ability to import it, considering: (i) the physical volume of its export; (ii) the relative price of its export measured in terms of its import price.

To evaluate the process described in this article, we used the Data Envelopment Data (DEA), a popular tool for measuring productivity in complex production systems. Charnes et al. (1978) developed DEA based on the frontier production concept of Debreu (1951) and Farrell (1957). It permits the analysis of a group of Decision Making Units (DMUs), according to chosen parameters (inputs and outputs) returning a ranking of the efficiency of DMUs. The DEA may also be used as a multi-criteria decision-making (MCDM) tool, where each alternative is a DMU, the inputs are usually "less-the-better" of performance type and outputs are "more-the-better" type (Cook et al., 2014).

Since 1978, scientific research has expanded DEA applications, using and developing several models. Castro and Frazzon (2017) concluded that there two clusters in academic research about the benchmark of units: one that collectively utilizes several benchmark methods and another that utilizes DEA models. Melo et al. (2017) applied DEA for benchmarking grain supply chain alternatives in Brazil and in the United States.

The literature review was a structured focus on applications of DEA in supply chains. We searched in May 2017, in Scopus database of the following words 'data envelopment analysis' and 'supply chain', limited by articles. We found 256 papers, $50.39 \%$ of them were published from 2013 on, indicating the increasing relevance of the theme in recent years. Gridgoroudis et al. (2014) applied Recursive Data Envelopment Analysis (RDEA) for the development of an optimal supply chain network of biomass for energy generation from Asia to Europe. But this paper considers multi-echelons of supply chain and not horizontal supply chains as ours.

Besides DEA applications as Gridgoroudis et al. (2014), among the most relevant regarding biomass supply chain modelling, exploring other alternative solutions it is relevant to mention: Forsberg (2000) applied life cycle inventory (LCI) to select bioenergy long-distance transportation chains, considering options of bales, pellets, solid biofuels, and electricity via international grid. Hamelinck et al. (2005) analyzed bioenergy supply chains from Europe and Latin America delivered in Western Europe, considering generic data such as distance, timing and scale of performance. Kanzian et al. (2013) used the weighted sum scalarization approach to optimize the solution of biomass supply network in Mid-Europe. Rentizelas and Li (2016) analyzed the feasibility of long-distance bio-energy supply chains.

Guimarães and Piefer (2016) concluded that, despite the great potential of the partnership between Brazil and Europe, the first as a biomass supplier and 
the second as a biomass consumer and a technology supplier for alternative energy sources, this partnership is not developed due to several barriers. Among obstacles, there is a lack of information and public knowledge. Given the previous context, this paper aims to investigate and benchmark supply chain alternatives of wood-derived biomass from Brazil to the United Kingdom.

\section{System Description}

Eucalyptus plantations cover 5.6 million hectares of planted tree area of Brazil. Their forests are located primarily in the following states: Minas Gerais (MG) (24\%), São Paulo (SP) (17\%) and MatoGrosso do Sul (MS) (15\%). Pine plantations cover 1.6 million hectares, concentrated in Paraná (PR) (42\%) and Santa Catarina (SC) (34\%) (IBA, 2016). We choose this origin states guided by: (i) the states with the current largest planted area, considering jointly eucalyptus and pines, i.e., Minas Gerais, São Paulo, MatoGrosso do Sul, Paraná and Santa Catarina (IBA, 2016); (ii) the states that are currently main wood exporters, Rio Grande do Sul and Amapá (MDIC, 2016).

The main ports that currently export wood were incorporated into the alternatives, i.e., Rio Grande (BR RIG), Santos (BR SSZ), São Francisco do Sul (BR SFS), Paranaguá (BR PNG), Itajaí (BR ITJ), Vitória (BR VIX) and Rio de Janeiro (BR RIO). The United Nations Code for Trade and Transportation Logistics (UN/LOCODE) is in brackets (MDIC, 2016). The routes and freight modes of transportation from principal state forests and exporting ports were drawn based on the National Infrastructure of Spatial Data (INDE, 2016). Table 1 summarizes the system description.

Table 1. Summary of the Brazilian System Description

\begin{tabular}{|c|c|c|}
\hline Eucalyptus Producing States & Wood Exporting Ports & UN/LOCODE \\
\hline Minas Gerais $(M G)$ & Rio Grande & $B R R I G$ \\
\hline São Paulo (SP) & Santana & $B R S A N$ \\
\hline \multirow[t]{2}{*}{ Mato Grosso do Sul (MS) } & Santos & $B R S S Z$ \\
\hline & São Francisco do Sul & $B R S F S$ \\
\hline Pine Producing States & Paranaguá & $B R P N G$ \\
\hline Santa Catarina (SC) & Itajaí & $B R I T J$ \\
\hline \multirow[t]{2}{*}{ Paraná $(P R)$} & Vitória & $B R V I X$ \\
\hline & Rio de Janeiro & $B R R I O$ \\
\hline \multicolumn{3}{|l|}{ Wood Exporting States } \\
\hline \multicolumn{3}{|l|}{ Amapá (AP) } \\
\hline Rio Grande do Sul (RS) & & \\
\hline
\end{tabular}

Figure 1 represents the position of each analyzed state of origin (abbreviations in green) and maritime routes (without scale). 
Figure 1. Sketch of States of Origin and Maritime Routes (without Scale)

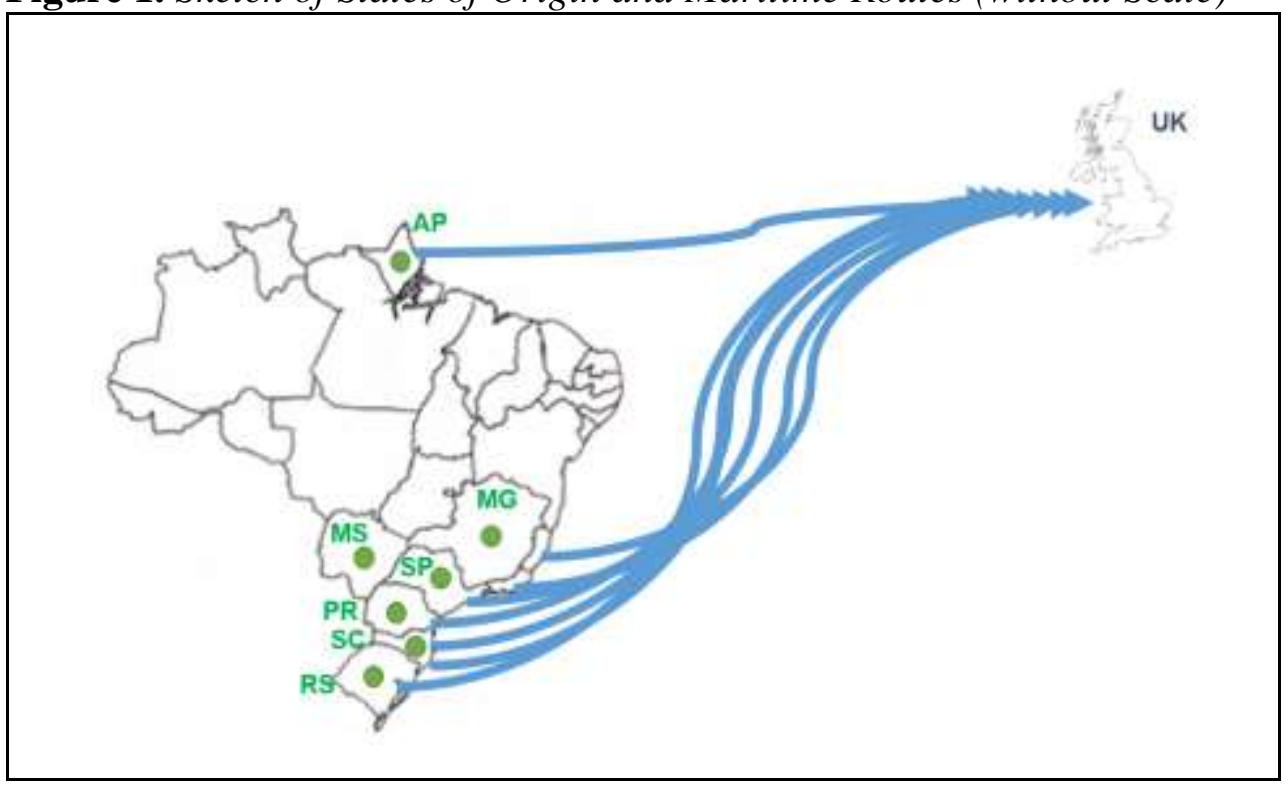

Three main supply chain scenarios were investigated, as follows:

Scenario 1 (named W and AW): The biomass (logs) is taken from Brazilian forests and sent to the UK, where it is torrefied and utilized in power generation. Ten main transportation routes (named here 'cases') by truck exclusively (named $\mathrm{W}$ followed by a digit from 1 to 10 ) were identified. Ten cases with alternative modes of transportation were identified (named AW followed by a digit from 1 to 10).

Scenario 2 (named P and AP): The logs are taken from the forest, pelletized in Brazil and exported. In the UK, pellets are torrefied and utilized for power generation. Ten cases of transportation by truck (named from P1 to P10) and two cases of alternative modes of freight transportation (named from AP1 and AP2).

Scenario 3 (named $\mathbf{Q}$ and AQ): The logs are taken from the forest, pelletized and torrefied in Brazil and exported. But the torrefaction plants do not presently exist in Brazil yet. This scenario considers a potential future solution that will require investment in torrefaction technology. Ten cases of transportation by truck (named from P1 to P10) and two cases of alternative modes of freight transportation (named from AP1 and AP2).

All scenarios consider unloading in the port of Immingham (GB IMM), which is one of the main ports handling biomass in the UK and rail transportation up to DRAX power plant, as a representative example of a large-scale biomass firing electricity generation facility.

Figure 2 is a schematic sketch of supply chain alternative scenarios. All cases are horizontal, i.e., only one unit (wood or facility) is considered for each case. 
The multiples echelons are not considered due to the limitations of the infrastructure of Brazil and the wide distances. It is considered that it is only possible to process the biomass in the geographically closest facility.

Figure 2. Schematic Sketch of Supply Chain Alternative Scenarios

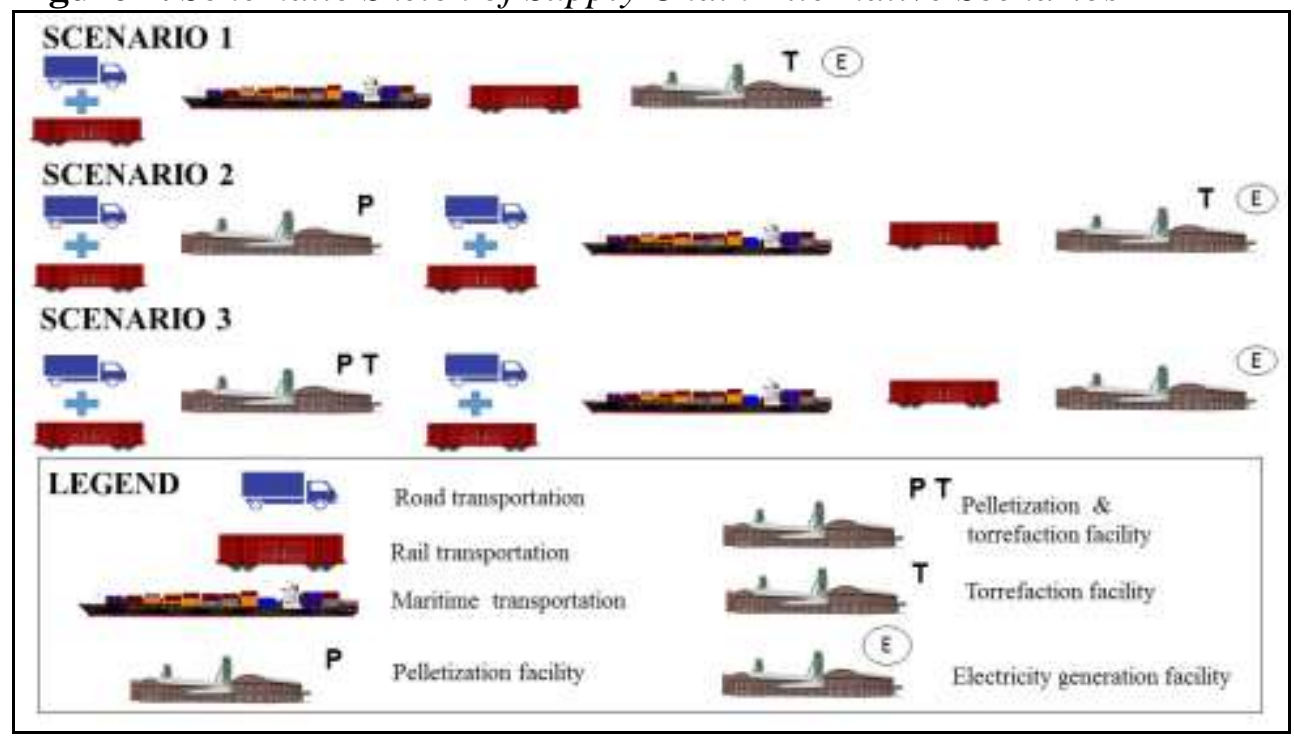

\section{Methodology}

The choice of the most appropriate DEA model and variables for solving a specific question is not a trivial one. Golany and Roll (1989) guided the choice of models and variables existing until that year. Cook and Seiford (2009) broadened it, publishing a taxonomy of general of DEA models. Cook et al. (2014) reviewed procedures of choice. All papers emphasize the importance of viewing the whole 'process' for applying DEA, the use of reliable data and focus on the main objective. Hence, this paper focused on working with the minimal possible variables that could explain the 'process' and relied on trusted data: energy consumption, emissions, and costs. The specific input variables are also the ones of the primary interest for the decision makers.

For freight transportation, we calculated the emissions and the fuel consumption with software EcoTransIT (2016). The software default parameters are shown in Table 2. Logistics costs came from ESAQ-LOQ database, the official agricultural Brazilian logistics database (SIFRECA, 2016). 
Vol. 5, No. 2 Melo et al.: An Assessment of Biomass Supply Chain: A DEA Application

Table 2. Parameters Utilized for Freight Emissions and Energy Consumption

\begin{tabular}{lcc}
\hline $\begin{array}{l}\text { EcoTransIT } \\
\text { Parameters }\end{array}$ & Road Freight & Rail Freight \\
\hline Input mode & Extended & Extended \\
Amount & 100 & 100 \\
Unit & Bulk and Unit & Bulk and Unit \\
& Loads (Tonnes) & Loads (Tonnes) \\
Type & Average goods & Average goods \\
t/TEU & 10 & 10 \\
Origin & City district & City district \\
Transport mode & Truck & Train \\
Vehicle type & $26-40 \mathrm{t}$ & Average Train (1000t) \\
Emission standard & EURO5 & Diesel \\
Load factor & $100 \%$ & $100 \%$ \\
Empty Trip Factor & $50 \%$ & $50 \%$ \\
Destination & UN/LOCODE & UN/LOCODE \\
\hline Sourc: EcoTrant 201 & &
\end{tabular}

Source: EcoTransIT 2016.

Table 3. Assumed Production Parameters

\begin{tabular}{|c|c|c|c|c|}
\hline & \multicolumn{2}{|c|}{ Pelleting plant } \\
\hline \multicolumn{3}{|c|}{ Both processes co-located - output: black pellets } & \multicolumn{2}{|c|}{ Output: white pellets } \\
\hline Parameters & Assumptions & Sources & Assumptions & Sources \\
\hline $\begin{array}{l}\text { Reference } \\
\text { capacity }\end{array}$ & $\begin{array}{c}\text { 200,000 tons Dry } \\
\text { substance/year } \\
\text { (output) }\end{array}$ & $\begin{array}{l}\text { Svanberg et } \\
\text { al. (2013) }\end{array}$ & $\begin{array}{c}200,000 \text { tons Dry } \\
\text { Substance/year } \\
\text { (Output) }\end{array}$ & $\begin{array}{l}\text { Uslu et al. } \\
\text { (2008) }\end{array}$ \\
\hline $\begin{array}{l}\text { Capital } \\
\text { expenditure for } \\
\text { reference } \\
\text { capacity }\end{array}$ & $\begin{array}{l}45.5 \text { Million } \\
\text { Euros (2013 } \\
\quad \text { values) }\end{array}$ & $\begin{array}{l}\text { Svanberg et } \\
\text { al. (2013) }\end{array}$ & $\begin{array}{l}\text { 9.43 Million Euros } \\
\text { (2014 values) }\end{array}$ & $\begin{array}{l}\text { Uslu et al. } \\
\text { (2008) }\end{array}$ \\
\hline $\begin{array}{l}\text { Maintenance } \\
\text { cost for } \\
\text { reference } \\
\text { capacity }\end{array}$ & $\begin{array}{l}2 \% \text { of capital } \\
\text { expenditure per } \\
\text { year }\end{array}$ & $\begin{array}{l}\text { Svanberg et } \\
\text { al. (2013) }\end{array}$ & $\begin{array}{l}5 \% \text { of Capital } \\
\text { expenditure per } \\
\text { year }\end{array}$ & $\begin{array}{l}\text { Uslu et al. } \\
\text { (2008) }\end{array}$ \\
\hline $\begin{array}{l}\text { Personnel } \\
\text { required for } \\
\text { reference } \\
\text { capacity }\end{array}$ & 24 & $\begin{array}{l}\text { Svanberg et } \\
\text { al. (2013) }\end{array}$ & $\begin{array}{l}\text { Assumed the same } \\
\text { as in torrefaction }\end{array}$ & \\
\hline Scale factor & 0.7 & $\begin{array}{l}\text { Svanberg et } \\
\text { al. (2013) }\end{array}$ & $0.7-0.8$ & $\begin{array}{l}\text { Uslu et al. } \\
\text { (2008) }\end{array}$ \\
\hline $\begin{array}{l}\text { Energy input in } \\
\text { process }\end{array}$ & $\begin{array}{l}193 \mathrm{kWh} \\
\text { electricity per } \\
\text { produced ton }\end{array}$ & $\begin{array}{l}\text { Batidzirai et } \\
\text { al. (2014) }\end{array}$ & $\begin{array}{l}22 \mathrm{kWh} \text { electricity } \\
\text { per produced ton }\end{array}$ & $\begin{array}{l}\text { Batidzirai et } \\
\text { al. (2014) }\end{array}$ \\
\hline
\end{tabular}

Source: Authors based on the identified references. 
We assumed production parameters based on literature as summarized in Table 3. We considered all costs in US dollars, converting to the average dollar quotation in the last 12 months. All calculations were done considering that 1 ton of torrefied biomass will achieve its final destination, the power plant and that there is a material loss of $1 \%$ for each stage of transportation.

Table 6 under Appendix presents the utilized calculated data. Golany and Roll (1989) suggested the following process for differentiating inputs and outputs: to perform the linear regression for each variable "one at once". A variable believed as input that presents a weak relationship with other variables (believed to also inputs) and a strong relationship with other variables believed to outputs may be, indeed, an input. The opposite is also true. The authors accentuated that this may not be considered a reliable rule, only an indication for carefully examining variables. Table 4 presents the results of correlation among variables proposed as inputs.

Table 4. The Linear Regression Results

\begin{tabular}{|c|c|c|c|c|}
\hline \multicolumn{5}{|c|}{ Correlations } \\
\hline & & $\begin{array}{c}\text { Cost } \\
\text { (USD/ton) }\end{array}$ & $\begin{array}{l}\text { Energy } \\
\text { (MJ/ ton) }\end{array}$ & $\begin{array}{c}\text { Emissions (kg of } \\
\mathrm{CO}_{2} \text { eq/ton) }\end{array}$ \\
\hline \multirow{3}{*}{ Cost (USD/ton) } & $\begin{array}{c}\text { Pearson } \\
\text { Correlation } \\
\end{array}$ & 1 & $0.364^{* *}$ & $0.255^{*}$ \\
\hline & Sig. (1-tailed) & & 0.008 & 0.047 \\
\hline & $\mathrm{N}$ & 44 & 44 & 44 \\
\hline \multirow{3}{*}{ Energy (MJ/ ton) } & $\begin{array}{l}\text { Pearson } \\
\text { Correlation }\end{array}$ & $-0.364^{* *}$ & 1 & $0.273^{*}$ \\
\hline & Sig. (1-tailed) & 0.008 & & 0.036 \\
\hline & $\mathrm{N}$ & 44 & 44 & 44 \\
\hline \multirow{3}{*}{$\begin{array}{c}\text { Emissions (kg of } \\
\text { CO2eq/ton) }\end{array}$} & $\begin{array}{c}\text { Pearson } \\
\text { Correlation }\end{array}$ & $0.255^{*}$ & $0.273^{*}$ & 1 \\
\hline & Sig. (1-tailed) & 0.047 & 0.036 & \\
\hline & $\mathrm{N}$ & 44 & 44 & 44 \\
\hline
\end{tabular}

* Correlation is significant at 0.01 level (1-tailed).

** Correlation is significant at 0.05 level (1-tailed).

As can be seen in Table 4, all variables present a correlation at the confidence level of $0.01 \%$ (emissions - cost, emissions - energy) or $0.05 \%$ (energy - cost). As expected they also present a weak correlation, respectively, 0.255, 0.273, and -0.364 . The negative signal between energy and cost is expected, once more requested energy normally implies into a higher freight cost.

The DEA models differ in orientation, they may minimize inputs, maximize outputs or do both simultaneously. The DEA also can be constant or variable in scale (Mariano and Rebelatto, 2014). In this case, we considered the use model with a constant scale, because all alternatives consider a constant and equal production. As all variables were calculated considering the delivery of 1 ton of torrefied biomass at the final destination and they present a weak relationship between each other, it was assumed a model where the variable where all inputs to 
be minimized with a unitary output. This case is similar to the index known as Benefit of Doubt (BoD) (OECD, 2008) and it can be mathematically represented as follows:

$$
\operatorname{Max}=\sum_{i=1}^{m} \boldsymbol{u}_{i} \cdot y_{i \mathrm{O}}
$$

Subject to:

$$
\begin{aligned}
& \sum_{j=1}^{n} v_{j} \cdot x_{j \mathrm{O}}=1 \\
& \sum_{i=1}^{m} u_{i} \cdot y_{i k}-\sum_{j=1}^{n} v_{j} \cdot x_{j k} \leq 0, k=1,2, \ldots, z
\end{aligned}
$$

Where:

$u_{i}=$ calculated weight to the product $\mathrm{i}$

$v_{j}=$ calculated weight to the product $\mathrm{j}$

$x_{j k}=$ quantity of input $\mathrm{j}$ to unit $\mathrm{k}$

$y_{i k}=$ quantity of output $\mathrm{i}$ to unit $\mathrm{k}$

$x_{j 0}=$ quantity of input $\mathrm{j}$ to analyzed unit

$y_{i 0}=$ quantity of output $\mathrm{i}$ to analyzed unit

$\mathrm{z}=$ number of analyzed units

$\mathrm{m}=$ number of products types

$\mathrm{n}=$ number of inputs types

$u_{i}$ and $v_{j} \geq 0$

\section{Results}

Through the evaluation of the proposed method, we measured the efficiency of the biomass supply chain alternatives from Brazil to the UK. We used the MATLAB software to calculate the efficiencies through DEA - CCR model with input orientation and Excel to tabulate the results. Table 5 presents the results of efficiency for the 44 analyzed DMUs. 
Table 5. Results of the DEA Model

\begin{tabular}{|c|c|c|c|c|}
\hline Code & Origin & Mode & Destination & Efficiency \\
\hline$A Q 2$ & Lages (SC) & Rail & São Francisco do Sul (SC) & 1 \\
\hline$\widetilde{\text { W3 }}$ & Amapari (AP) & Road & Santana (AP) & 1 \\
\hline$A W 7$ & Guarapuava (SC) & Rail & São Francisco do Sul (SC) & 1 \\
\hline$Q^{9}$ & Telêmaco Borba (PR) & Road & Paranaguá (PR) & 1 \\
\hline$A W 10$ & Cataguases (MG) & Rail & Vitória (ES) & 1 \\
\hline$A W 4$ & Vespasiano (MG) & Rail & Vitória (ES) & 0.999671213 \\
\hline$A W 3$ & Três Lagoas (MS) & Rail & Paranaguá (PR) & 0.990185519 \\
\hline$A W 2$ & Três Lagoas (MS) & Rail & São Francisco do Sul (SC) & 0.989929028 \\
\hline$P 9$ & Telêmaco Borba (PR) & Road & Paranaguá (PR) & 0.962718822 \\
\hline$P 8$ & Amapari (AP) & Road & Santana (AP) & 0.937295693 \\
\hline$A W 6$ & Apucarana (PR) & Road + Rail & Paranaguá (PR) & 0.936260377 \\
\hline$Q 8$ & Oiapoque (AP) & Road & Santana (AP) & 0.90896032 \\
\hline$Q 4$ & Canoinhas (SC) & Road & São Francisco do Sul (SC) & 0.905362054 \\
\hline Q5 & Lages (SC) & Road & Itajaí (SC) & 0.901977036 \\
\hline$P 4$ & Canoinhas (SC) & Road & São Francisco do Sul (SC) & 0.89982068 \\
\hline$P 5$ & Lages (SC) & Road & Itajaí (SC) & 0.885481336 \\
\hline W9 & Canoinhas (SC) & Road & Itajaí (SC) & 0.869859994 \\
\hline$A W 5$ & Telêmaco Borba (PR) & Road + Rail & Paranaguá (PR) & 0.847521405 \\
\hline W10 & Lages (SC) & Road & São Francisco do Sul (SC) & 0.840384236 \\
\hline W8 & Telêmaco Borba (PR) & Road & Paranaguá (PR) & 0.82503575 \\
\hline W1 & Encruzilhada do Sul (RS) & Road & Rio Grande (RS) & 0.824924192 \\
\hline$A W 1$ & Encruzilhada do Sul (RS) & Road + Rail & Rio Grande (RS) & 0.819762178 \\
\hline W7 & Conceição da Barra (MG) & Road & Rio de Janeiro (RJ) & 0.809988121 \\
\hline$Q 6$ & Conceição da Barra (MG) & Road & Rio de Janeiro (RJ) & 0.786761933 \\
\hline$A W 9$ & Lages $(\mathrm{SC})$ & Road + Rail & São Francisco do Sul (SC) & 0.77179443 \\
\hline$A W 8$ & Lages (SC) & Road + Rail & Rio Grande (RS) & 0.767323628 \\
\hline$Q 10$ & Telêmaco Borba (PR) & Road & Paranaguá (PR) & 0.75872525 \\
\hline W4 & Bauru (SP) & Road & Santos (SP) & 0.757671913 \\
\hline$Q 1$ & Bauru (SP) & Road & Santos (SP) & 0.738886529 \\
\hline$P 10$ & Telêmaco Borba (PR) & Road & Paranaguá (PR) & 0.732920655 \\
\hline$A P 2$ & Lages (SC) & Rail & São Francisco do Sul (SC) & 0.730892085 \\
\hline$Q 3$ & Encruzilhada do Sul (RS) & Road & Rio Grande (RS) & 0.730006651 \\
\hline$Q 2$ & Bauru (SP) & Road & São Francisco do Sul (SC) & 0.72449231 \\
\hline P6 & Conceição da Barra (MG) & Road & Rio de Janeiro (RJ) & 0.718733021 \\
\hline$A Q 1$ & Encruzilhada do Sul (RS) & Road + Rail & Rio Grande (RS) & 0.693147126 \\
\hline$\widetilde{W 5}$ & Bauru (SP) & Road & São Francisco do Sul (SC) & 0.684363535 \\
\hline$P 1$ & Bauru (SP) & Road & Santos (SP) & 0.680087659 \\
\hline$W 2$ & São Jorge do Oiapoque (AP) & Road & Santana (AP) & 0.67798574 \\
\hline$P 3$ & Encruzilhada do Sul (RS) & Road & Rio Grande (RS) & 0.653977178 \\
\hline$P 2$ & Bauru (SP) & Road & São Francisco do Sul (SC) & 0.652917189 \\
\hline$A P 1$ & Encruzilhada do Sul (RS) & Road + Rail & Rio Grande (RS) & 0.644293407 \\
\hline$Q 7$ & Três Lagoas (MS) & Road & São Francisco do Sul (SC) & 0.587773673 \\
\hline W6 & Três Lagoas (MS) & Road & São Francisco do Sul (SC) & 0.576082562 \\
\hline$P 7$ & Três Lagoas (MS) & Road & São Francisco do Sul (SC) & 0.535065029 \\
\hline
\end{tabular}




\section{Discussion}

Cases with alternative modes of transportation were more efficient than those with exclusively road transportation. Considering the 11 most efficient DMUs $(25 \%)$, seven of them presented alternative modes of transportation. On the other hand, considering the 11 least efficient DMUs (25\%), only two of them presented alternative modes of transportation, suggesting that rail freight may be a factor that contributes for increasing efficiency.

Both cases that count on rail transportation are originated in Southern State Rio Grande do Sul (RS) and the destination port of Rio Grande, one of them belongs to Scenario 2 (AP1) and another to Scenario 3 (AQ1). This fact may that the current rail infrastructure (rail web) in the region is not the most adequate for flowing wood production. Although RS is the greatest wood exporting Brazilian state, the closest terminals from the woods do not operate with wood products. The results suggest that decision makers should focus investments in rail infrastructure of Rio Grande do Sul (RS).

The most efficient cases are concentrated in a specific scenario? Figure 3 presents the cases of Scenario 1 that are among the most and the least efficient quarters. Scenario 1 considers direct exportation of wood logs. There are seven cases among the most efficient and only three among the least, suggesting that direct exportation of logs tend to be more efficient in the current conditions.

\section{Figure 3. Summary of the Cases of Scenario 1}

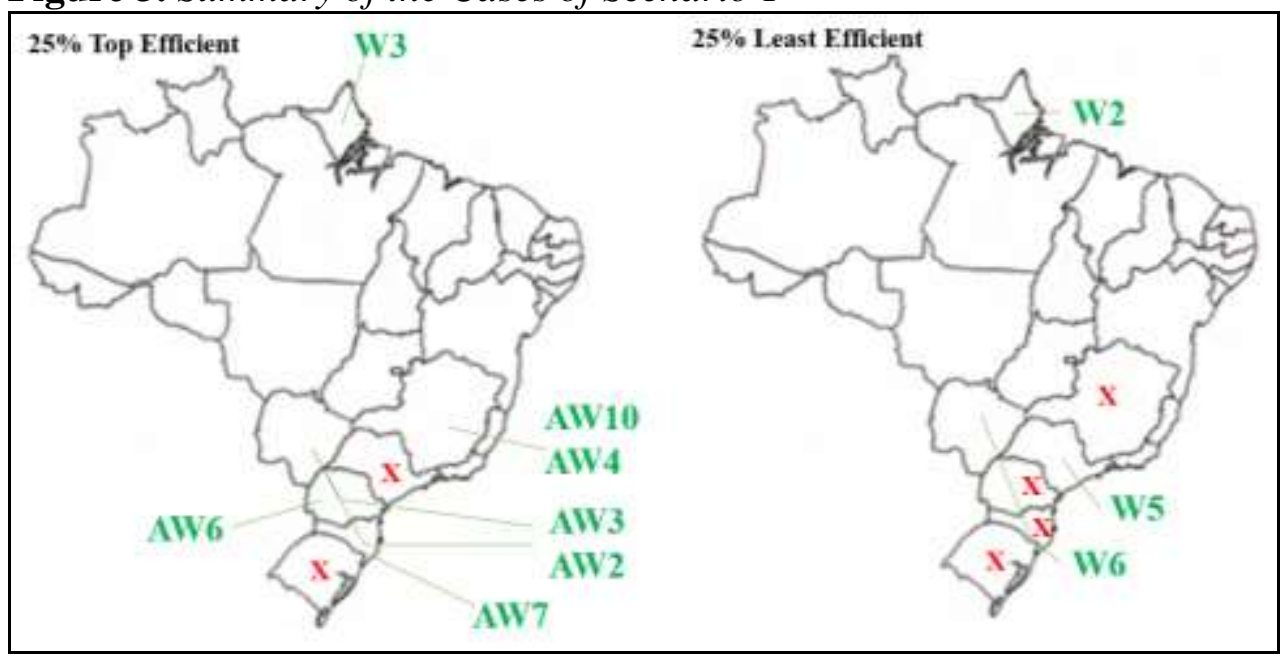

Figure 3 points that cases originated from São Paulo (SP) and Rio Grande do Sul (RS) are not among the most efficient. In contrast, there are neither cases originated from RS among the least efficient, suggesting RS is at an intermediary condition of efficiency. Six of the seven cases of the efficiency of Scenario 1 count on rail transportation.

The only exception, i.e. an efficient case without rail freight, is W3, originated in the Amazon State of Amapá (AP). This is a short-distance case because the wood is close to the exporting port of Santana. The W2 is a case from the same state that is among the least efficient, because, in this case, the analyzed wood 
was more distant from the port, reinforcing that road transportation may be efficient only for short-distance routes. MatoGrosso do Sul (MS) simultaneously present cases among the most efficient (AW2 and AW3) and the least (W6). For this state, the same wood was considered as the point of origin, the distance is the same and the difference is the use of trains for increasing the efficiency. It is remarkable to remember that the biggest cellulose plants of Brazil are in MS.

Another observation is that only cases from Minas Gerais (MG) through the port of Vitória (AW10 and AW4) were considered efficient. The cases originated from the same State, but exported through the port of Rio de Janeiro were not among the efficient, suggesting the longer distances and port fees may be factors that reduce efficiency. But the port of Vitória is focused on ore exportation, if the ore demand is high, port fees may become prohibitive for wood exportations.

For decision makers, it means the most efficient cases that should be the focus of deeper investment studies are those that involve exporting logs by road from Amapá (W3) and logs by rail from Paraná (AW6) and Santa Catarina (AW7).

To keep the investigation whether the most efficient cases are concentrated in a specific scenario, Figure 4 presents the cases of Scenario 2 and 3 that are among the most and the least efficient quarters. The Scenario 2 considers the existing pellet facilities and the exportation of biomass in pellet format. The Scenario 3 considers the cost construction and operation of torrefaction facilities jointly to the existing pellet facilities and the exportation of terrified biomass.

Figure 4. Summary of the Cases of Scenario 2 and Scenario 3

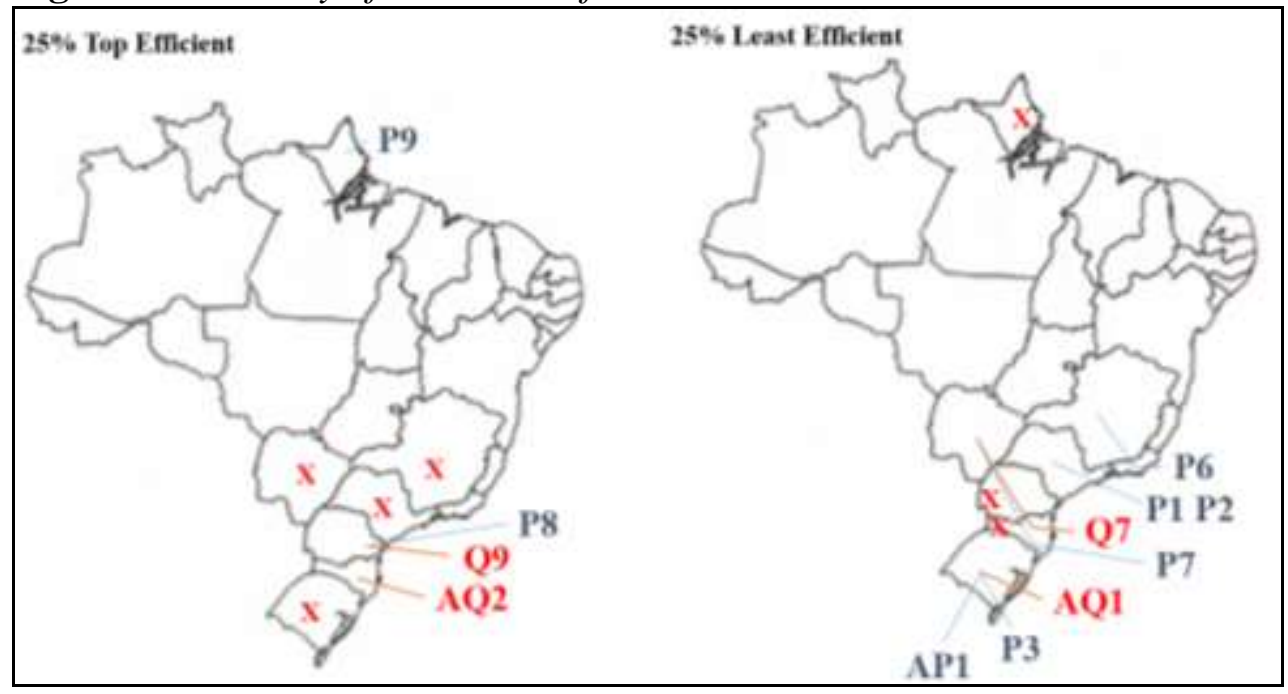

Among the most efficient, there are two from Scenario 2, one from Paraná (P8) and one from Amapá (P9). There are two cases from Scenario 3, one from Paraná (Q9) and one from Santa Catarina (AQ2). The last present alternative mode of transportation. They are all short-distance routes. That suggests decision makers may deeper investment prospects in these States.

Among the least efficient quarter, there are six cases of the Scenario 2 and two of the Scenario 3. Two cases are originated in Rio Grande do Sul and 
considers an alternative mode of transportation (AQ1 and AP1), reinforcing the use of rail in this State is not adequately distributed for wood transportation. There are no cases originated from Amapá, Paraná and Santa Catarina among the least efficient. The inefficient case from Minas Gerais utilizes the port of Rio de Janeiro for exporting.

For decision makers, this represents that using biomass from Amapá (logs or pellets) transported by road (there is no operating rail infrastructure yet in the State) may be the focus of investment analysis. It equally points that the use of biomass (logs and torrefied biomass) from Paraná and Santa Catarina transported by rail may be interesting, as well as pellets from Paraná.

The decision to build a torrefaction facility may be focused on these two States. Investments in rail infrastructure should be focused on Amapá and Rio Grande do Sul. The DEA results pointed out the priority may not be on Mato Grosso do Sul, Minas Gerais, and São Paulo.

MatoGrosso do Sul is the Brazilian state with largest forest planted area, but it is in a central position, simultaneously far from Atlantic and Pacific Oceans and it counts with the biggest cellulose factories of the continent. The exclusion of São Paulo and Minas Gerais from the top performer alternatives may be due to the expensive logistics costs, mainly port fees. It is important to remember that a significant percentage of the wood produced in Minas Geraisis already used for steel production and in São Paulo for cellulose.

\section{Conclusions}

This paper utilized the data envelopment analysis (DEA) to analyze alternatives of biomass supply chain from Brazil to the United Kingdom (UK). The pool pointed that exporting it without refined processes, i.e., in logs, may the most efficient solution; exporting it in pellet format may be efficient only considering Northern State of Amapá and Southern State of Paraná; and installing a torrefaction plant in Brazil may create an efficient supply chain depending on the region, but further investment analysis may be performed. It is important to mention that, although alternatives were compared and the best performers identified, this does not mean they are profitable, once this was not the focus of the study.

In this context, according to the Central European Biomass Conference (2014) in Graz, Austria, several torrefaction technology companies can invest in plants at full scale. These plants, due available biomass resources, can be most likely be situated in Brazil, Asia, Eastern Africa, etc.

Considering the biomass Borges et al. (2016) found that torrefaction is feasible for the energy conditioning of Eucalyptus biomass (5.6 million hectares of planted tree area of Brazil.) and improves the biomass to a higher quality biofuel. Therefore, the logistics aspects are improved due to torrefaction. The process causes significant changes in Eucalyptus properties, reducing water and increasing energy density, in this way, permitting the transportation of more energy with less consumption and emissions. Our paper pointed out that, although 
torrefied biomass reduces volume and increase energy storage, the installation of new torrefaction facilities may be economically interesting only in some Brazilian States, such as Paraná and Santa Catarina, due to mainly logistics obstacles for flowing biomass from plants to exporting ports (distance and costs). Due to this, Brazil can be an interesting place to future investments in torrefaction industry. A final decision demands further studies on investments, given that several aspects of the decision making regarding investments are beyond the scope of this paper.

The DEA model proved to be useful once it excluded low performer options. It also pointed to Paraná, Santa Catarina, and Amapá as the most efficient alternatives, while highlighted the condition in which intermediary may improve (Rio Grande do Sul with rail transportation). DEA is a useful tool for decisionmakers in any condition where it is important to determine which alternative present the best performance. Furthermore, it determines the alternatives in which investments should focus on, and provides several suggestions on how to improve the performance average of analyzed alternatives. The application of DEA for supply chain performance is relatively new but promising.

\section{Acknowledgments}

Our thanks to Foundation CAPES (Comissão de Aperfeiçoamento de Pessoal do Nível Superior) and FAPESP (Fundação de Amparo à Pesquisa do Estado de São Paulo).

\section{References}

Batidzirai, B., van der Hilst, F., Meerman, H., Junginger, M. and Faaij, A. 2014. Optimization potential of biomass supply chains with torrefaction technology. Biofuels Bioprod Biorefining, 8, 253-282. http://dx.doi.org/10.1002/bbb.1458.

Borges, A. C. P., Alves, C. T and Torres, E. A. 2016.Torrified Eucalyptus Grandis Characteization as Biomass to Using in Industrial Scale.Chemical Engineering Transaction, 49, 283-288.

Castro, V. F. and Frazzon, E. M. 2017.Benchmarking of best practices: an overview of the academic literature. Benchmarking: An International Journal, 24, 3, 750-774. http://dx.doi.org/10.1108/BIJ-03-2016-0031.

Central European Biomass Conference. 2014. Development of torrefaction technologies and impacts on global bioenergy use and international bioenergy trade. Graz, Austria. Available at: http://bit.ly/2nPnoSC.[Accessed 10 May 2017].

Charnes, A., Cooper, W. W. and Rhodes, E. L. 1978.Measuring the efficiency of decision making units.European Journal of Operational Research, 2, 6, 429-444. https://doi.org/10.1016/0377-2217(78)90138-8.

Cook, D. W. and Seiford, L. M. 2009. Data Envelopment Analysis (DEA)-Thirty years on. European Journal of Operational Research, 192, 1-17. http://dx.doi. org/10.1016/j.ejor.2008.01.032.

Cook, D. W., Tone, K. and Zhu, J. 2014. Data envelopment analysis: Prior to choosing a model. Omega, 44, 1-4. 
Debreu, G. 1951. The coefficient of resource utilization.Econometrica, 19, 3,273-292.

DelfimNetto, A. and Ikeda, A. 2007.Estratégias de Desenvolvimento [Strategies of Development]. In Sociedade e Economia: Estratégias de Desenvolvimento, Chapter 4, Brasília.

EcoTransIT. 2016. [Online].Available from: http://www.ecotransit.org/. [Accessed 27 March 2017]

European Comission. 2017. Renewable Energy Progress Report. Brussel. Available from: http://bit.ly/2mQMnDJ. [Accessed 27 April 2017].

Farrell, M. J. 1957. The measurement of productive efficiency. Journal of the Royal Statistical Society, Series A, 120, 253-281.

Forsberg, G. 2000. Biomass energy transport - Analysis of bioenergy transport chains using life cycle inventory method. Biomass and Bioenergy, 19, 17-30. https://doi. org/10.1016/S0961-9534(00)00020-9.

Golany, B. and Roll, Y. 1989. An Application Procedure for DEA.Omega, 17, 3, 237-250.

Gridgoroudis, E., Petridis, K. and Arabatzis, G. 2014. RDEA: A recursive DEA based algorithm for the optimal design of biomass supply chain networks. Renewable Energy, 71, 113-122. https://doi.org/10.1016/j.renene.2014.05.001.

Guimarães, C. and Piefer, N. 2016. Brazil: (Future) green energy power and strategic partner for the EU? Comparative European Politics, 1-22. DOI: 10.1057/cep.2016. 12.

Hamelinck, C. N., Suurs, R. A. A. and Faaij, A. P. C. 2005. International bioenergy transport costs and energy balance. Biomass and Bioenergy, 29, 114-134. doi: 10. 1016/j.biombioe.2005.04.002.

IBA - Indústria Brasileira de Árvores [Brazilian Tree Industry]. 2016. Annual Report 2015 [Online]. Available from: http://bit.ly/2ieKeAk. [Accessed 27 March 2017].

INDE - Infraestrutura Nacional de Dados Espaciais[National Infrastructure of Spatial Data]. 2016. Geo Serviços, Visualizador de Mapas, Mapas Iterativos [Online]. Available from: http://www.inde.gov.br/geo-servicos/visualizador-de-mapas. [Accessed 27 March 2017].

Kazian, C., Kühmaier, M., Zazgornik, J. and Stampfer, K. 2013. Design of forest energy supply networks using multi-objective optimization. Biomass and Bioenergy, 54, 294-302. http://dx.doi.org/10.1016/j.biombioe.2013.10.009.

Mariano, E. B. and Rebelatto, D. A. N. 2014. Transformation of wealth produced into quality of life: analysis of the social efficiency of nation-states with the DEA's triple index approach. Journal of the Operational Research Society, 65, 16641681. http://dx.doi.org/10.1057/jors.2013.132.

MDIC - Ministério da Indústria, Comércio Exterior e Serviços [Ministry of Industry, Exterior Commerce and Services]. 2016. AliceWeb2 [Online]. Available from: http://aliceweb.mdic.gov.br/.[Accessed 27 March 2017].

Melo, I. C., Alves Júnior, P. N., Périco, A. E., Guzman, M. S. and Rebelatto, D. A. N. 2017. Benchmarking freight transportation corridors and routes with data envelopment analysis (DEA).Benchmarking: an International Journal [In Press].

MMA - Ministério do Meio Ambiente [Ministry of Environment]. 2013. Forests [Florestas]. Available from: http://bit.ly/2sbMkJM. [Accessed 27 March 2017].

OECD, European Commission, Joint Research Centre. 2008. Handbook on constructing composite indicators: methodology and user guide. OECD Publishing.

Rentizelas, A. and Li, J. 2016. Techno-economic and carbon emissions analysis of biomass torrefaction downstream in international bioenergy supply chains for cofiring. Energy, 114, 1, 129-142. http://bit.ly/2BFMHjv.

SIFRECA - ESALQ-LOG. 2016. Mercado de Fretes [Freight Market][Online]. Available from: http://esalqlog.esalq.usp.br/sifreca/.[Accessed 28 March 2017]. 
Svanberg, M., Olofsson, I., Flodén, J. and Nordin A. 2013. Analysing biomass torrefaction supply chain costs.Bioresource Technology, 142, 287-296.

Uslu A, Faaij A. P. and Bergman, P. C. 2008. Pre-treatment technologies, and their effect on international bioenergy supply chain logistics. Techno-economic evaluation of torrefaction, fast pyrolysis and pelletisation.Energy, 33, 1206-1223. 
Vol. 5, No. 2 Melo et al.: An Assessment of Biomass Supply Chain: A DEA Application

\section{Appendix}

Table 6. Calculated Data

\begin{tabular}{|c|c|c|c|}
\hline Code & Cost (USD/ton) & Energy (MJ/ ton) & $\begin{array}{c}\text { Emissions (kg of } \\
\mathrm{CO}_{2} \mathrm{eq} / \text { ton) }\end{array}$ \\
\hline$W 1$ & 128.55 & 12269.851 & 397 \\
\hline$W 2$ & 140.68 & 15524.931 & 642 \\
\hline W3 & 94.32 & 10565.798 & 270 \\
\hline W4 & 142.49 & 13263.121 & 472 \\
\hline W5 & 141.53 & 15298.39 & 624 \\
\hline W6 & 168.34 & 18166.013 & 840 \\
\hline$W 7$ & 123.94 & 12760.522 & 433 \\
\hline$W 8$ & 119.64 & 12605.041 & 401 \\
\hline W9 & 114.12 & 11931.062 & 371 \\
\hline$W 10$ & 115.05 & 12465.925 & 411 \\
\hline$A W I$ & 143.59 & 11808.067 & 364 \\
\hline$A W 2$ & 179.91 & 9477.541 & 188 \\
\hline$A W 3$ & 177.76 & 9475.086 & 188 \\
\hline$A W 4$ & 141.42 & 9389.786 & 180 \\
\hline$A W 5$ & 147.40 & 11119.273 & 313 \\
\hline AW6 & 137.13 & 10020.816 & 228 \\
\hline$A W 7$ & 123.72 & 9452.137 & 185 \\
\hline$A W 8$ & 187.79 & 12227.035 & 394 \\
\hline$A W 9$ & 167.45 & 12156.207 & 389 \\
\hline$A W 10$ & 126.70 & 9382.093 & 180 \\
\hline$P 1$ & 118.47 & 31477.913 & 478 \\
\hline$P 2$ & 123.40 & 33080.041 & 601 \\
\hline$P 3$ & 123.20 & 32201.176 & 531 \\
\hline$P 4$ & 89.54 & 29458.748 & 330 \\
\hline$P 5$ & 90.99 & 29393.471 & 322 \\
\hline P6 & 112.10 & 31530.561 & 482 \\
\hline$P 7$ & 153.04 & 36251.223 & 839 \\
\hline$P 8$ & 85.96 & 29247.754 & 308 \\
\hline$P 9$ & 83.69 & 28658.214 & 266 \\
\hline$P 10$ & 109.93 & 31464.807 & 477 \\
\hline$A P 1$ & 125.91 & 30946.996 & 440 \\
\hline$A P 2$ & 140.45 & 27005.143 & 145 \\
\hline$Q 1$ & 114.83 & 23406.085 & 361 \\
\hline$Q 2$ & 116.52 & 24291.188 & 430 \\
\hline$Q 3$ & 116.21 & 23702.734 & 382 \\
\hline$Q 4$ & 90.35 & 21492.484 & 220 \\
\hline$Q 5$ & 90.92 & 21409.128 & 212 \\
\hline$Q 6$ & 106.43 & 22984.991 & 329 \\
\hline$Q 7$ & 146.99 & 27550.046 & 674 \\
\hline$Q 8$ & 89.82 & 21529.803 & 218 \\
\hline$Q^{9}$ & 80.57 & 20331.702 & 130 \\
\hline$Q 10$ & 110.75 & 23559.36 & 372 \\
\hline \multirow[t]{2}{*}{$A Q 1$} & 124.91 & 23173.145 & 346 \\
\hline & 145.03 & 19265.754 & 53 \\
\hline
\end{tabular}

